6th International Conference on Science \& Social Research 2019

https://cssr.uitm.edu.my/2019/

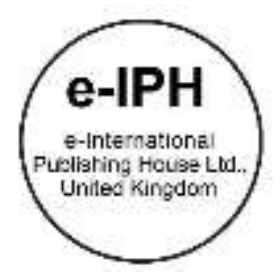

\title{
Floral Motifs Design on Sarawak Traditional Malay Songket
}

\author{
Asrul Asshadi Mohamad Morni ${ }^{1}$, Mohd Azhar Samin², Rafeah Legino 3 \\ 1 Design Technology Programme, Faculty of Applied \& Creative Arts, Universiti Malaysia Sarawak, 94300 Kota Samarahan, Sarawak \\ Malaysia \\ 2 Faculty of Art \& Design, Universiti Teknologi MARA, 40450 Shah Alam, Selangor Malaysia \\ ${ }^{3}$ Formgiving Research Group, Faculty of Art \& Design, Universiti Teknologi MARA, 40450 Shah Alam, Selangor Malaysia
}

masrul@unimas.my, azharsamin@uitm.edu.my, rafeahl@uitm.edu.my

Tel of 1 st Author: Tel: $+6013-8331671$

\begin{abstract}
This study is partly an ongoing project to identify the floral motifs design on Sarawak traditional Malay songket. This project begins with a review of related literature that provides an example of textile-also supported with visual data on Sarawak traditional Malay songket gathered from the field visit, which is captured into the digital compilation. The identification process defined that the Sarawak traditional Malay songket motifs mainly develop from various floral sources reflecting and inspiring nature. This study shared different design Malay songket motifs in Sarawak and represent their tradition in textile heritage.
\end{abstract}

Keywords: Malay; Motifs; Sarawak; Songket

eISSN: 2398-4287@ 2021. The Authors. Published for AMER ABRA cE-Bs by e-International Publishing House, Ltd., UK. This is an open access article under the CC BYNC-ND license (http://creativecommons.org/licenses/by-nc-nd/4.0/). Peer-review under responsibility of AMER (Association of Malaysian Environment-Behaviour Researchers), ABRA (Association of Behavioural Researchers on Asians/Africans/Arabians) and cE-Bs (Centre for Environment-Behaviour Studies), Faculty of Architecture, Planning \& Surveying, Universiti Teknologi MARA, Malaysia.

DOI: https://doi.org/10.21834/ebpj.v6iSI4.2902

\subsection{Introduction}

Malay traditional songket in Sarawak shared many traditions and significant elements that need to be sustained towards various platforms. In terms of design character, the design depicted from nature contributed a valuable aesthetic in the Malay design. The Sarawak traditional Malay songket shows how the exquisite piece through textile portrays the Sarawak Malay culture identity. Throughout this project, the Sarawak traditional Malay songket examples show the diverse design and pattern. The floral element was inspired by nature and was clearly defined from the instance of songket. The images showing the motifs were shared and revealed floral motifs design for this textile tradition.

\subsection{Related Literature Review}

The previous and recent related studies defined the textile context. At first, the studies where the textile was associated with material culture and expanded through their symbolic values deal with consumer responses and share their differences depend on their countries and regions (Crane \& Bovone, 2006). The study on clothing culture shows how this stage shares the character on national identity, which is in line with social, gender, body, religion, politics, and other aspects (Richardson, 2017). The study on clothing within the anthropological approaches was expanded. The most noticeable trend concerns society, custom, and implementation "that considers the dressed body as both subjects of, dress practice" (Hansen, 2004, p. 369). The expansion of a similar approach was also highlighted in the international compilation of anthropological and ethnological papers presented at this congress, which was also organised as part

eISSN: 2398-4287@ 2021. The Authors. Published for AMER ABRA cE-Bs by e-International Publishing House, Ltd., UK. This is an open access article under the CC BYNC-ND license (http://creativecommons.org/licenses/by-nc-nd/4.0/). Peer-review under responsibility of AMER (Association of Malaysian Environment-Behaviour Researchers), ABRA (Association of Behavioural Researchers on Asians/Africans/Arabians) and cE-Bs (Centre for Environment-Behaviour Studies), Faculty of Architecture, Planning \& Surveying, Universiti Teknologi MARA, Malaysia.

DOI: https://doi.org/10.21834/ebpj.v6iSI4.2902 
of the conference. The majority of the papers dealt with themes of art and aesthetics, which were closely related to clothing culture and material culture in the comprehensive overview of clothing culture and material culture (Cordwell \& Schwarz, 2011). The compilation of clothing culture was established in Richardson (2017) where examines clothing concerning such fundamental problems as national identity, class distinction, gender, the body, religion, and politics, providing a window into one of the most fascinating yet little-understood elements of history. Rubinstein (2018) stated that country like in American culture, dress regulations have various meanings and connotations, like dress in societal discourse, nineteenth-century theories of clothing, as well as those that had to do with clothing codes. In Sweden, the study looks at the attire of landowning farmers in inland Sweden throughout industrialisation in the nineteenth century from a gendered perspective. Clothing is viewed as a property and a good within the context of European commerce and influence. It demonstrates how clothing became a medium of expression that altered as the industry progressed and how gender became a significant issue in the supply and manufacture of clothing. Clothing in the studied region transitioned from being a regional fashion, characterised by similarities in material and workmanship between men's and women's garments, to becoming a part of general fashion, with an emphasis on contrasts between men's and women's garments (Ulväng, 2021). On the other hand, the expansion related to this study is also referred to as the closest example in Southeast Asia.

The detailed study covering clear information on textiles in the Pacific also related to business activities such as how silk is transmitted to Asia and distributed worldwide within technology. Cotton and fabric evolved in the Pacific as a result of industrial development, and wool was also marketed in Australia (Owen, 2017). In the Indian economic history, textiles were significant through production, cloth and trade regions, trade, trade and network distribution, as well as the culture of consumption (Machado, \& Campbell, 2018). Initially, fabric selection for a given application depends, taking cost and price into account, on the performance requirements imposed by the end-use or the desired characteristics of the end-user aesthetically. In fact, many applications, such as clothing, home furnishings and industrial fabrics, use fabrics (Adanur, 2020). No doubt, when we discuss about textile in South East Asia, especially songket, nature is always related with the various level in several countries. Janpourtaher (2019) discovered that a Songket sarong from the 19th century belonging to the Royal Family. The example was preserved in the collection of the National Museum of Malaysia. In Brunei, Lopes (2021) stated that in Brunei, songket is represented their historical and cultural setting entails more than urban and infrastructure growth, technical innovation, and industrialisation. It's also about the reinterpretation of cultural identity, social selfhood, and collective identity. The other recent compilation on textile, which shares various types of fabric, includes the songket is also stated in Solyom (2021). An example is Indonesian textiles. This heritage is diverse and rich, worthy of admiration on both artistic and technical grounds. They are culturally significant, still performing essential roles in magic and ritual as well as everyday life, even though some are no longer created and the traditions from which they arose are being lost. A significant recent study where Maxwell (2012) work closely with textiles, which is the value of textile is more than any other medium, convey a visual history of a country's culture and craft traditions. Southeast Asian textiles, which include a variety of traditional textiles, are among the most commonly used by the local community. Also, Uchino (2005) study on the Palembang songket's socio-cultural history.

Songket is a traditional Malaysian textile made by Malay weavers. It is a unique fabric woven in silk or cotton with metallic gold or silver threads added. Typically, the patterns and motifs on this woven fabric cover the entire sarong (Nawawi, 1989). According to Selvanayagam (1990), a study on songket in Malaysia found that this fabric belongs to the brocade family of textiles. It's a magnificent, opulent ceremonial fabric made of silk or cotton and delicately designed with gold (and occasionally silver) threads that stand out in subtle relief against the background material. The fabric's shimmering effect is created by the interplay of light and delicate shadow on it, making it unquestionably the "queen" among handwoven fabrics. Additionally, as Yatim (2006) stated, Malay songkets are inextricably linked to Malay textile art. When we study Malay textiles, we recognise songket as a Malay fashion and textile art form. Songket cloth has been woven in Southeast Asia for over two centuries, according to Stankard (2010), and its materiality symbolises Malaysia's cultural legacy, tradition, and national identity. Furthermore, the study by Nawawi et al. (2015) is based on geometric symmetries on Malaysian songket patterns, notably border patterns from sarung and shawl, and reported the results of songket pattern categorisation into frieze patterns. The early study is also stated about songket, when Brooke (2001) stated about the use of costumes in Sarawak Malay women as regards the use of selayah keringkam and Songket Sarawak. Lady Margaret Brooke showed her admiration toward the art of Malay women costumes of the period until her own wearing costumes with a head full of jewellery up to use selayah keringkam and Songket. Some excerpts from her statement in describing her admiration for the work of art textiles by the Malay women in Sarawak.

But talking of these sarongs and the wonderful cloths manufactured by the women of Sarawak, it always surprises me when I consider, given the idea that Sarawak was such an uncivilised country when the first Rajah went there, and that its people were sunk in a state of barbarism, how it was possible that the women kind of the Malay population living in the place evolved the marvellous embroideries and bro-cades I hat nearly all the women of Sarawak are capable of weaving. The patterns on these golden clothes are very similar, for no 'kain tape' worn by the better classes of Sarawak women is considered quite correct unless the stuff, powdered all over its ground of red silk with open rosettes made of gold thread, is divided by a broad band of differently marked in gold thread. ( Brook, 1913, p.30)

\subsection{Methodology}

Recent and previous studies were used to identify the relevant data that was chosen for this study. Then, within the context of this study, the analysis and classification were carried out in accordance with the concept of identification of the types of songket motifs in Sarawak, which was developed. Further, a few selected examples of Sarawak's songket were analysed, and the types of motifs were identified based on the type and character of floral elements used in the composition. The example of the songket that analysis is the kain songket 
belatak, kain songket berturus and kain songket bertabur. The specifics of this outcome will be discussed and elaborated in-depth in the following segment.

\subsection{Finding and Discussion}

For this study, the sources and types of floral themes were discovered by utilising the example of Sarawak's songket (see Figure 1 in a and b). Significantly, the common element that easily defines Sarawak's songket is the geometrical character. First, the kain songket belatak, this luxurious gold-plated songket fabric, is woven by songket experts in Sarawak for weddings or high socio-economic status. Usually, the body of this songket fabric does not have many types of motifs, but it is woven so that only its gold thread is visible. This fabric is also known as Jong Sarat, especially in the northern state of Sarawak. Most of the designs are stylised and transformed into the geometric motif and form harmony patterns. Therefore, there various types of floral motif character was found for this study. And all the local floral elements mostly use in the example of songket. The traditional motif element of bunga tampuk manggis (mangosteen)that usually found in kain songket belatak. This motif was depicted from a young mangosteen fruit flower. Uniquely, this motif is recognised and "it has certain benefits and symbolises gentleness, generosity, and wisdom in speech" (Suhana, 2018, p. 83).

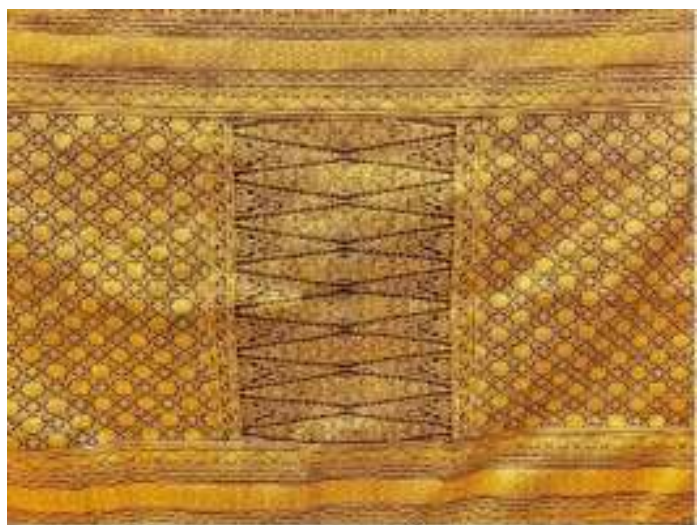

(a)

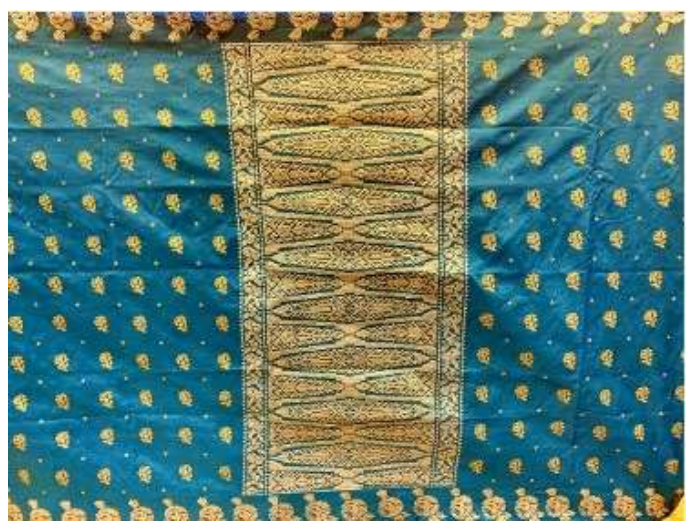

(b)

Figure 1: The example of Sarawak traditional songket from Lawas (a) and from Rajang (b) use floral motifs

Then, kain songket berturus is a reference to a fabric striped from top to bottom. The head of the songket is decorated with geometric patterns and sometimes interspersed with abstract patterns in the form of rose patterns of sitting roses or floating roses. Usually, the body of the fabric is woven in a colourful square pattern or one colour (heart red, navy blue, purple, mangosteen red, orange, moss green and earthy colours). The body of the cloth is usually decorated with gold thread threads that alternately alternate and repeat the pattern but are beautiful. Suitable for a variety of occasions to be made of kain kuyuk cloth or kain tapeh. The bunga cengkih (clove) motif is another example of local flora that has influenced the creation of songket motif design (Abdullah et al., 2015). This tropical spice consists of small reddish-brown flower buds that are used as a spice, which are found in kain songket berturus. Indeed, as a reflection of this motif, cloves were essential in the earliest spice trade and are known to be indigenous to the island of spices, where they are still grown today.

At last, the kain songket bertabur this songket has features such as the top of the songket is quite wide, and its body is filled with scattered patterns. Among the flower motifs sown are bunga tanjung, melur, baling, bintang, tampok pedada, tampok manggis, bunga raya, mawar and orkid. The upper or lower clamps and the inner or outer clamps of the cloth head are usually motifs leuk pakuk (awan larat), tampok pedada, kuda laut and kiapuk. The famous pattern is the bridal flower edge or the bridal side, which is a combination of several geometric and abstract motifs combined and repeated horizontally. At the same time, the top of the bridal side leads into the body of the cloth. This type of fabric is also known as kain lungsi or kain Brunei.Sarawak's songket uses the bunga cermai motif on kain songket bertabur. In addition to its traditional health benefits, cermai (also known as gooseberry) can be easily depicted as a single motif that is balanced and harmonised with the other elements in the songket. Consequently, the floral motifs in songket are derived from various types of flowers, and the motif's personality has been formulated with multiple types of character, either in an organic or geometric concept.

\subsection{Conclusion}

To sum up, the findings of this study clearly demonstrate the floral motifs that were used in the design of Sarawak's traditional Malay songket. a systematic process involving the review of relevant literature, which begins with a comprehensive review of the history of textile development In addition to the clothing and material culture, the considerations include the function and type of textile, which provides for songket. The visual data on Sarawak traditional Malay songket that was gathered during the field visit has also been included in the digital compilation to supplement it. After a thorough investigation, it was discovered that the traditional Malay songket motifs used in Sarawak are predominantly derived from a variety of floral sources that reflect and are inspired by natural phenomena. The floral motif and the way it is used clearly demonstrate the common thread of traditional motif such as the bunga tampuk manggis, the bunga cengkih, 
the bunga cermai, and other motif, among others. The results of this study revealed that Malay songket motifs found in Sarawak were unique in character, and that their textile heritage tradition was represented in this study.

\section{Acknowledgements}

The authors would like to acknowledge the Research Management Center (RMC), Universiti Teknologi MARA, for funding under the grants of the 600-IRMI/DANA 5/3/BESTARI (124/2018) for this project.

\section{References}

Abdullah, N., Nawawi, N. M., Legino, R., Khalid, M. F. M., Ahmad, N. H., Ismail, N. H., \& Basaree, R. O. (2015). Classification of frieze patterns in Malay songket textile. Int. Collogium Art Des. Educ. Res.

Adanur, S. (2020). Handbook of weaving. CRC press

Cordwell, J.M., \& Schwarz, R. A. (Eds.). (2011). The fabrics of culture: The anthropology of clothing and adornment. Walter de Gruyter

Crane, D., \& Bovone, L. (2006). Approaches to material culture: The sociology of fashion and clothing. Poetics, 34(6), 319-333.

Hansen, K. T. (2004). The world in dress: Anthropological perspectives on clothing, fashion, and culture. Annu. Rev. Anthropol., 33, 369-392.

Janpourtaher, M. (2019). A scientific approach of preservation treatment and restoration procedures on historical royal songket sarong. International Journal of Conservation Science, 10(1).

Lopes, R. O. (2021). Defining Bruneian Cultural Identity Through Contemporary Artistic Practice. Engaging Modern Brunei: Research on language, literature, and culture, $199-214$

Machado, P., Fee, S., \& Campbell, G. (Eds.). (2018). Textile Trades, Consumer Cultures, and the Material Worlds of the Indian Ocean: An Ocean of Cloth. Springer.

Marzal, M., Erwin, A., \& Yusron Wikarya, M. P. (2017). Perkembangan Bentuk Produk, Motif dan Fungsi Produk Songket Melayu Pekanbaru Riau. Serupa The Journal of Art Education, 4(2).

Maxwell, R. (2012). Textiles of Southeast Asia: Trade, tradition, and transformation. Tuttle Publishing

Nawawi, N. M. (1989). Malaysian songket. DBP.

Nawawi, N. M., Abdullah, N., Legino, R., Khalid, M. F. M., Ahmad, N. H., Basaree, R. O., \& Ismail, N. H. (2015). Classification of frieze patterns in Malay songket textile. In International Colloquium of Art and Design Education Research (i-CADER 2014) (pp. 491-500). Springer, Singapore

Owen, N. (2017). Textile Displacement and the Status of Women in Southeast Asia. Textiles in the Pacific, 1500-1900, 255

Richardson, C. (Ed.). (2017). Clothing Culture, 1350-1650. Routledge.

Rubinstein, R. (2018). Dress codes: Meanings and messages in American culture. Routledge.

Selvanayagam, G. I. (1990). Songket: Malaysia's woven treasure. Singapore: Oxford University Press

Solyom, B., \& Solyom, G. (2021). Textiles of the Indonesian archipelago. University of Hawaii Press.

Stankard, S. (2010). Textile Praxis: The Case for Malaysian Hand-Woven Songket. Royal College of Art (United Kingdom).

Uchino, M. (2005). Socio-cultural history of Palembang songket. Indonesia and the Malay World, 33(96), 205-223.

Ulväng, M. (2021). Clothing Economy and Clothing Culture: The Farm Wardrobe from a Gendered Perspective in Nineteenth-Century Sweden. Gender \& History.

Yatim, O. M., Borhan, Z. A., Ahmad, M. N., \& Samad, M. A. A. (2006). Estetika dan keindahan songket Melayu. Jurnal Pengajian Melayu, 17, 1-15. 